\title{
Psychiatry in Japan
}

On 31 March 1987, ITV broadcast Viewpoint '87: Forgotten Millions, a film made for Central Independent Television by co-producers David Cohen and Joan Shenton. I went in response to an invitation for the College to send someone to a preview. The film gives a confused message of good and bad, mostly bad, from a quick look at the care of the mentally ill in Japan, USA, India and Egypt. England got off lightly this time but we were reminded of David Cohen's earlier film, I was in Broadmoor which stimulated human rights lawyer Etsuro Totsuka to look at psychiatric care in Japan. He has exposed an appalling state of affairs but is within sight of getting important changes in legislation achieved. The influence of foreign psychiatrists is said to be important and Japan may be sensitive to our response.

The vignettes of psychiatric institutions in Egypt and India were interesting, depressing, sometimes refreshing but there were no important conclusions that I could see. Just an overwhelming feeling of the enormity of so much poverty.

New York is a different planet. Overwhelming in its own inimitable way, it certainly provides an object lesson in how not to empty the mental hospitals. Since 1960 , the number of mental hospital in-patients in New York fell from 93,000 to less than 20,000; and in the USA, from 800,000 to less than 283,000 today. I thought there was only a superficial resemblance to the kind of future people are fearing and predicting here and I suspect that New York is not like anywhere else, not even in the United States. Across America, it is now alleged that the mental institutions cream off the easy patients, the 'worried well' and reject the rest so that people can only obtain psychiatric care by desperate measures. We are shown a patient who at last got himself looked after by pushing somebody in front of a subway train. The film shows the wandering mentally ill in New York accommodated in walk-in shelters looking like the concourse of Waterloo Station, with rows and rows and rows of 600 beds patrolled by security guards. And murders occur. Then there are municipal schemes and voluntary schemes trying to clean up the problem, provide food and comfort or at least a wash to these destitute people. The film could be used selectively to fuel arguments, if not propaganda, against the run down of our own mental hospitals and the dangers of community care not properly funded or planned.

There is one residual important question from all this for the College and it will come back. This concerns the wish for our support in the fight to get Japanese care of the mentally ill into the twentieth century. It seems that $85 \%$ of their mental hospitals are privately owned and the directors tend to be doctors with no training in psychiatry-if they are doctors at all. Virtually all the inmates are held on orders and Etsuro Totsuka is hoping soon to have brought Japan in line with Britain in 1930 if it becomes possible for these people to be there as voluntary patients. It is touch and go whether he will get this through the legislature and it seems only a remote prospect to think of informal patients, community care etc. The proportion of Japanese people committed to mental institutions is about 20 times the WHO suggested figures (in Japan this means 250,000 people compared with 7,000 mental hospital patients in Britain). On the other hand you never see a dosser, a tramp or a person raving in Japan's streets. They have all been put away somewhere. At one hospital, 223 patients died in three years, some of these were clubbed to death and there have at last been scandals, exposures and prosecutions.

The film was extensively reported in the main national newspapers and there were two relevant items in the Lancet, (21 March 1987). On page 678 (Round the World) there was a synopsis of the film. On page 676 (Law and Psychiatry) there was an article describing the problems and recent developments in Japan. In particular, it specifies the Kyoto Principles formulated at the International Forum on Mental Health Law Reform held in Kyoto in January 1987. There was also an article by Larry Gostin, Director of the American Society for Law and Medicine on 'Patients or Prisoners' in The Guardian, (11 March 1987). The Kyoto Principles are bland, self-evident minimum requirements agreed unanimously at the forum and it is startling that they should be the subject of debate in Japan:

(1) Mentally ill persons should receive humane, dignified, and professional treatment.

(2) Mentally ill persons should not be discriminated against by reason of their mental illness.

(3) Voluntary admission should be encouraged whenever hospital treatment is necessary.

(4) There should be an impartial and informal hearing before an independent tribunal to decide, within a reasonable time of admission, whether an involuntary patient needs continued hospital care.

(5) Hospital patients should enjoy as free an environment as possible, and should be able to communicate with other persons.

It is interesting and a little ironic that the scenes from New York in the film vividly illustrate problems raised by American participants at Kyoto. The fear of replicating these New York scenes makes it unexpectedly difficult to agree guidelines for mental health law reform in Japan and elsewhere. They remark that 'the proposal of community mental health care as an alternative to hospital care, has acquired the status of international dogma. It is based on a 
myth that has turned into a nightmare'. 'The caring community does not exist. . . and the chronically mentally ill are diverted into less caring institutions such as dosshouses or prisons....

Etsuro Totsuka emphasises that the Japanese are quite sensitive to international attention and it would help the cause for reform if the Japanese know that the Royal College of Psychiatrists is watching and interested. New mental health laws now being prepared bring Japan to the level of Britain in 1930 (when statutory "Voluntary patients" appeared) but three important elements are missing in the current draft. Firstly, committal can be decided by an individual hospital doctor. Secondly, detained patients have no right to any independent review. Thirdly, many unjust discriminations against mental patients remain on the Statute
Book. (Art galleries, national monuments, local government assemblies, public baths and swimming pools being barred to them, for example). Etsuro Totsuka also says that there is virtually no psychiatry in Japanese medical education and doctors wishing to specialise have to get their training outside the country.

He would like to see the Royal College of Psychiatrists making a declaration that it welcomes and strongly supports the Kyoto Principles and urges their colleagues in Japan to work wholeheartedly for the adoption of these principles in practice.

SANDY BOURNE The Tavistock Clinic London NW3

\section{Forthcoming Events}

The Annual Guest Lecture 1987 of the Leukaemia Research Fund will be delivered by $\mathrm{Dr}$ J. Michael Bishop, Professor of Microbiology and Immunology, University of California, San Francisco, on 16 November 1987 at 5.30 p.m. at the Jarvis Lecture Theatre, 66 Portland Place, London W1. Admission by ticket only. Tickets will be issued free from September 1987. Further information: The Secretary, Leukaemia Research Fund, 43 Great Ormond Street, London WCIN 3JJ (telephone 014050101 ).

The International Society for Adolescent Psychiatry's 2nd International Congress will be held in Geneva from 10-13 July 1988. The theme will be 'Psychotic breakdowns in adolescence' and the languages will be French and English. Information: 2nd International Congress for Adolescent Psychiatry, PO Box 50, CH-1211 Geneva 8, Switzerland. (Congress Scientific Coordinator: Ian Frank; Congress Administrative Secretary: Christiane Bowen).

The Joint Liaison Psychiatry Group/Psychosomatic Research Society will hold a half-day meeting on the afternoon of 21 October 1987 in the Department of Psychiatry, Leicester General Hospital, entitled 'Topics of Local Psychosomatic Research'. Those interested in attending this seminar should contact: Dr C. J. Thomas, Department of Liaison Psychiatry, Leicester General Hospital, Gwendolen Road, Leicester LE5 4PW.

The Twelifth Annual Training Meeting of the Association for Family Therapy will be held at the University of York from 10-12 September 1987. The theme will be 'Making Family Therapy Work' and the Opening Speakers will be Mrs Gill
Gorell-Barnes, Tavistock Clinic and Institute of Family Therapy, London, and Mr Charles O'Brian, Oxford Polytechnic. Participants will also be able to attend a variety of training Workshops. Research and Writing for Publications Workshops also available this year. Further information and application form: Dr Michael Sevitt, 7 Upper Park Road, Kingston upon Thames KT2 5LB (telephone 015464173 evenings, 0372729136 daytime).

The World Pychiatric Association Regional Symposium, hosted by the American Psychiatric Association, will be held at the Washington Hilton Hotel from 13-16 October 1988. The theme will be 'The Research and Clinical Interface for Psychiatric Disorders'. Detailed information and a call for papers will be available by 1 September 1987 . Further information: Ellen Mercer, Office of International Affairs, American Psychiatric Association, $1400 \mathrm{~K}$ Street, NW, Washington, DC 20005, USA.

A symposium on 'Psychiatric Diagnosis', co-sponsored by the WPA Section on Nomenclature and Classification in conjunction with the Second World Basque Conference, will be held in Bilbao, Spain from 12-14 November 1987. Information: Dr Juan Mezzich, Department of Psychiatry, University of Pittsburgh, 3811 O'Hara Street, Pittsburgh, PA 15213, USA.

A Congress on Psychogeriatry: Prevention and Therapentic Aspects (XX Anniversary of the Julie Renson Foundation) will be held at the Palais des Congress, Brussels, from 29-31 October 1987. Information: Julie Renson Foundation, Rue Forestière, 12, 1050 Bruxelles, Belgium. 